\title{
Better Off
}

National Cancer Institute

\section{Source}

National Cancer Institute. Better Off. NCI Thesaurus. Code C95554.

Being in more desirable circumstances. 